\title{
Physico-chemical pretreatment and fungal biotreatment for park wastes and cattle dung for biogas production
}

\author{
Sameh S. Ali ${ }^{1,2^{*}}$ and Jianzhong Sun ${ }^{2}$
}

*Correspondence: samh_-
samir@science.tanta.edu.eg
${ }^{2}$ Biofuels Institute, Jiangsu
University, Zhenjiang 212013,
China
Full list of author information
is available at the end of the
article

\begin{abstract}
With the rising demand for renewable energy and environmental protection, anaerobic digestion of biogas technology has attracted considerable attention within the scientific community. The effect of physico-chemical pretreatment on cellulose degradation followed by fungal treatment by Aspergillus terreus and Trichoderma viride to treat cellulosic biomass for enhancing its digestibility was investigated. The tested substrate was digested with and without physical, chemical, and biological treatment. Fresh leaves, dry leaves and cattle dung were characterized by a total solids content 35, 84 and $17 \%$, volatile solids content $81.2,59.49$ and $64.5 \%$ and C/N ratio 31, 45.4 and 13.6, respectively. Biogas total volume was determined using water replacement technique, while methane volume was determined using precipitation of $\mathrm{CO}_{2}$ in $20 \% \mathrm{NaOH}$ solution. Pretreatment steps were carried out by using mechanical and chemical pretreatments using $2.5 \% \mathrm{NaOH}$ mixed with $2.5 \% \mathrm{NH}_{4} \mathrm{OH}$ for 15 days, followed by biological treatment of $A$. terreus and $T$. viride. The potential of pretreatment of substrate was studied at regular intervals of $0,7,14,21,28,35,42,49,56,63$ and 70 days determining the change in chemical and physical compositions of used substrates. Biogas production was 102.6 and $125.9 \mathrm{~L} / \mathrm{KgVS}$ from untreated and pretreated substrate, respectively. On the other hand, methane production was 61.4 and $79.8 \mathrm{~L} / \mathrm{KgVS}$ from untreated and pretreated substrate, respectively. In conclusion, Physical (milling), chemical $(\mathrm{NaOH}$ and $\mathrm{NH}_{4} \mathrm{OH}$ ) pretreatment in addition to fungal (A. terreus and T. viride) treatment for the tested substrate prior to AD was an efficient process for improvement of biogas and methane production.
\end{abstract}

Keywords: Cellulosic biomass, Pretreatment, Biogas, Methane

\section{Background}

The consumption of renewable energy is dramatically increasing, along with energy security concerns, efforts to mitigate the environmental impact of conventional fuels, and improvements in living standards and renewable technologies. Bioenergy can play a central role in promoting renewable alternatives. In fact, bioenergy is estimated to be the fourth largest energy resource in the world (Chen and Lee 2014) due to its renewable and widely applicable characteristics and its abundance. Forestry resources, agricultural resources, sewage and industrial organic wastewater, municipal solid wastes, live-stock and poultry dung and biogas are major categories for use. Biogas, which is generally

(C) 2015 Ali and Sun. This article is distributed under the terms of the Creative Commons Attribution 4.0 International License (http:// creativecommons.org/licenses/by/4.0/), which permits unrestricted use, distribution, and reproduction in any medium, provided you give appropriate credit to the original author(s) and the source, provide a link to the Creative Commons license, and indicate if changes were made. 
referring to gas from anaerobic digestion (AD) units, is a promising means of addressing global energy needs and providing multiple environmental benefits (Jiang et al. 2011). Biogas not only significantly reduces the costs of treating waste (Holm-Nielsen et al. 2009) but also has a relatively low feedstock cost. In addition, biogas has a lower sale price compared with diesel and petrol.

Biogas is generated from a digestion process under anaerobic conditions whose application is rapidly emerging as a viable means for providing continuous power generation. The AD cycle represents an integrated system of a physiological process of microbial and energy metabolism, as well as raw materials processing under specific conditions to produce biogas which is composed of methane and carbon dioxide and trace gases (Wu 2012). The pretreatment of wastes before AD is considered an effective method to improve biodegradability and biogas production from lignocellulosic materials by speeding up the hydrolysis step (Chen et al. 2005). Usual pretreatment methods including physical, chemical and biological may be used singly or in combinations (Sari and Budiyono 2014). Lignocellulose wastes mainly include crop residues and logging residues with crop residues making up the majority. For China, more than 800 million metric tons of waste agricultural straw is produced per year (Bi et al. 2009). However, this waste cannot be digested by itself due to recalcitrant materials (lignin, cellulose and hemi-cellulose) that result in low biodegradation and poor digestion performance; thus, extra accumulative measures are needed to start the digestive process such as pre-treatment and inoculums (Zhang et al. 2011).

Physical pretreatments were carried out to break down the cellular structure of biomass and to increase the specific surface area. This provided the chance for the lytic action of bacterial enzymes and reduction of viscosity in digesters, which is particularly important for cellulosic substrates (Schell and Harwood 1994). Chemical reagents are predominantly used for pretreatment of lignocelluloses materials due to their low-cost and high efficacy. By changing the properties of raw material, e.g., increasing the surface area, removing or dissolving lignin and hemicellulose, and reducing the crystallinity of cellulose, chemical reagents make lignocellulosic biomass more biodegradable and accessible to anaerobic microorganisms (Sun et al. 2014; Mao et al. 2015).

Microbiological pretreatment can speed up the degradation rate of substrates in anaerobic digestion. Bacterial and fungal cellulose-, hemicellulose- and starch-degrading enzymes are responsible for enhancing the substrate digestibility (Muñoz et al. 2014). However, the microbial community is sensitive to variations in the operating conditions applied. Thus, the AD process, if improperly managed, would become unstable and result in reduced biogas production. Although previous studies have discussed AD development, most focused on only one aspect (such as technology, mechanism, factors affecting efficiency, etc.) to minimize this instability (Munk et al. 2010) or on one substrate (such as livestock manure, urban solid waste, food waste, crop straw, etc.). Fungi, particularly those that attack lignin, are mainly used in the pretreatment of lignocellulosic biomass for biogas production. Several fungi classes, including brown-rot, whiterot and soft-rot fungi (i.e., Ceriporiopsis subvermispora, Auricularia auricula-judae, Trichoderma reesei), and basidiomycetes (e.g., Ischnoderma resinosum and Fomitella fraxinea) have been used for pretreatment with white-rot fungi being the most effective through the action of lignin-degrading enzymes (e.g., peroxidases and laccase) (Zheng 
et al. 2014). After fungal pretreatment, a 5-15\% increase in the methane yield was obtained (Mackulak et al. 2012; Sun et al. 2014). The aim of this study is to improve the performance of anaerobic digestion of lignocellulosic park wastes and cattle dung, by applying physico-chemical pretreatments and fungal fungal treatment. In addition, daily and cumulative production of biogas, $\mathrm{CH}_{4}$ and $\mathrm{CO}_{2}$ is evaluated for both untreated and pretreated. Beside, study of the changes in different parameters that control the anaerobic digestion process.

\section{Methods}

Procurement of the materials

Samples of Park wastes (fresh and dry leaves) were collected from Faculty of Science at Tanta University parks. The fresh and dried leaves were chopped to 3-4 $\mathrm{cm}$ and were stored in polythene bags at room temperature. Cattle dung sample of the various microbial inocula for $\mathrm{AD}$ had been collected from a farm at El-Hamrawy village in Kafr ElSheikh Governorate, Egypt and placed in sealed plastic bags and then frozen at $-20{ }^{\circ} \mathrm{C}$, to retain microbial viability in the collected sample (Williams and Withers 2012).

\section{Physical pretreatment}

Before mixing with cattle dung, mechanical pretreatment was performed on the collected park wastes (fresh and dried leaves), by using a cutting mill and then sieved with $2 \mathrm{~mm}$ screen (Bochmann and Montgomery 2013) In order to achieve a squeezing for the cellular structure of park wastes for the pretreatment prior to anaerobic digestion.

\section{Chemical pretreatment}

Lignocellulosic materials are resistant to hydrolysis due to their structure and composition. Alkali addition causes swelling of lignocelluloses and partial lignin solubilisation (Kong et al., 1992). Park wastes were soaked in combination of $2.5 \% \mathrm{NaOH}$ and $2.5 \%$ $\mathrm{NH}_{4} \mathrm{OH}$ for 15 days in a closed plastic container to improve delignification levels (Elumalai et al. 2014). After chemical pretreatment step, $\mathrm{pH}$ was adjusted using dilute $1 \mathrm{~N}$ $\mathrm{HCl}$ to achieve a suitable medium for the biological pretreatment and fungal growth (Alvarez et al. 2013).

\section{Biological treatment}

\section{Isolation and identification of fungi}

Fungi were isolated from an old digester slurry (cattle dung and food waste mixture) using a tenfold serial dilution-plating technique on potato dextrose agar (PDA) plates into which $30 \mu \mathrm{g}$ of chloramphenicol was added. The plates were incubated at $25^{\circ} \mathrm{C}$. The cultures were observed daily and fungal growth was subcultured onto fresh PDA plates until pure isolates were obtained. The plates were identified macroscopically and microscopically using colony color, type, texture, shape and growth pattern according to the detailed drawing of the features and identification manual and guides of Gilman (1959), Booth (1971), Moubasher (1993) and Blackwell (2011). The isolated fungi were maintained on potato dextrose agar (PDA) slant and stored at $4{ }^{\circ} \mathrm{C}$. 


\section{Preparation of inocula}

Inoculum suspensions were prepared from fresh, mature cultures grown on PDA and Sabouraud agar. The colonies were covered with $5 \mathrm{~mL}$ of distilled water. Tween 20 (5\%) was added to facilitate inoculum preparation. The mixture was collected in a sterile tube with vortexing for $15 \mathrm{~s}$ (Petrikkou et al. 2001).

\section{Preparation of starter culture}

In order to obtain biogas and methane production, the method of Maramba (1978) was employed. Cattle dung, which is well known to contain methanogenic consortia, will be used to start the inoculation of the digester. The starter material was prepared 20 days before the start of charging fresh substrate in the digester. A volume of $500 \mathrm{~mL}$ of starter was prepared at 1:1 ratio (water to cattle dung) and placed in a closed plastic bottle connected with a submerged tube, so all the gas can come out without air entrance to the drum.

\section{Experiment set-up}

Two digesters each contained a mixture of $125 \mathrm{~g}$ of fresh leaves, $125 \mathrm{~g}$ of dried leaves and $250 \mathrm{~g}$ of cattle dung. The substrate in the first digester was milled to $2 \mathrm{~mm}$ then pretreated with alkaline solution $\left(2.5 \% \mathrm{NaOH}\right.$ mixed with $\left.2.5 \% \mathrm{NH}_{4} \mathrm{OH}\right)$ and the $\mathrm{pH}$ was adjusted by using diluted $1 \mathrm{~N} \mathrm{HCl}$ to be a suitable medium ( $\mathrm{pH}$ 7.1) for biological treatment by two isolated and identified fungi (Aspergillus terreus and Trichoderma viride) isolated from the old digester slurry. The second digester was left without any pretreatment as a control. Fungal treatment of park wastes was kept at $25^{\circ} \mathrm{C}$ for 7 days followed by incubation of the both digesters for 70 days on incubator shaker $\left(35^{\circ} \mathrm{C}, 120 \mathrm{rpm}\right)$ to assist in the mixing process as shown in Fig. 1. Physico-chemical analyses samples were collected from effluent outlet at the bottom of the digester at regular intervals of $0,7,14$, $21,28,35,42,49,56,63$ and 70 to determine $\mathrm{pH}$, EC and $\mathrm{C} / \mathrm{N}$ ratio.

\section{Biogas, methane and carbon dioxide volume}

Daily methane volume was determined using a system developed in our laboratory of Microbiology at Faculty of Science, Tanta University. The system consists of four units connected together using connecting pipelines, as shown in Fig. 1. The first unit contains a simple designed batch plastic digester equipped with biogas outlet, solid sample outlet, thermometer and valve spout effluent outlet. The second unit is an application for water replacement technique which is used to measure total volume of biogas. Ergüder et al.

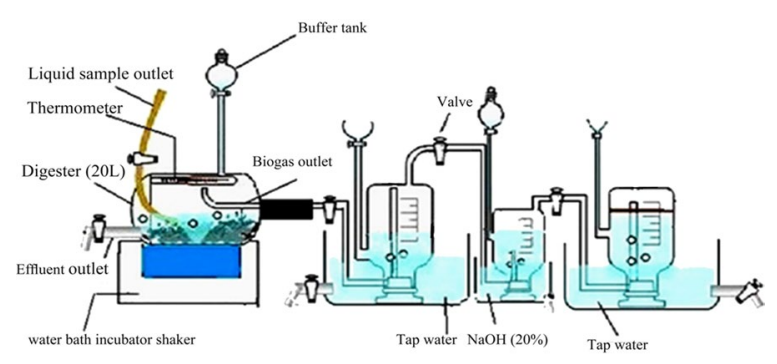

Fig. 1 Schematic biogas batch digester 
(2000) reported that the gas production in batch reactors was determined by a water displacement device. The third unit used to determine the volume of methane and carbon dioxide gases by passing produced biogas in $20 \% \mathrm{NaOH}$. After biogas elevation, the container shaken and left for $30 \mathrm{~min}$ to measure the methane volume according to (Manilla et al. 2001) and Wojciech (2012) who reported that sodium hydroxide $(\mathrm{NaOH})$ reacts with carbon dioxide $\left(\mathrm{CO}_{2}\right)$ through chemical processes. When the produced biogas passes through sodium hydroxide, sodium bicarbonate $\left(\mathrm{NaHCO}_{3}\right)$ is formed according to Eq. (1). In this way, carbon dioxide and water moisture were removed from the entire gas.

$$
\mathrm{NaOH}(a q)+\mathrm{CO}_{2}(g) \rightarrow \mathrm{NaHCO}_{3}(\mathrm{aq})
$$

The content of $\mathrm{CH}_{4}$ in biogas was determined as follows: A known volume of the headspace gas was produced in a two liter container to determine the total volume of biogas by water replacement technique $\left(\mathrm{V}_{\mathrm{B}}\right)$, and it was injected into another container which contained $20 \% \mathrm{NaOH}$ solution. This container was shaken manually for 3-4 min so that all the $\mathrm{CO}_{2}$ could be absorbed in the concentrated $\mathrm{NaOH}$ solution, then it was left for $30 \mathrm{~min}$. The volume of remaining gas $\left(\mathrm{V}_{\mathrm{M}}\right)$ refers to the produced methane volume. Hence, the volume of methane and carbon dioxide $\left(\mathrm{V}_{\mathrm{C}}\right)$ can be calculated according to Eq. (2) (Ergüder et al. 2000; Tippayawong and Thanompongchart 2010; Drosg et al. 2013).

$$
V_{B=} V_{M}+V_{C}
$$

The fourth unit used to collect and store all purified methane gas.

\section{Physico-chemical analysis}

The physico-chemical properties of park wastes before and through anaerobic digestion process were implemented at Ministry of Agriculture and land reclamation laboratories in Gharbia in addition to Kafr El-Sheikh University central laboratory of environmental studies (KUCLES).

\section{Total solids (TS) and volatile solids (VS)}

Analyses of samples were carried out using APHA standard methods (APHA 1995) by taking a known weigh of sample in dried aluminum container. At the beginning, the weight of empty containers alone and containers with samples together was determined. The containers were placed in a furnace at $105^{\circ} \mathrm{C}$ for $12 \mathrm{~h}$ to evaporate water for total solids (TS) calculation. Weight of the containers was determined. For volatile solids (VS) calculations, the contents were put in another furnace at $550{ }^{\circ} \mathrm{C}$ for $3 \mathrm{~h}$. The weight was then recorded. Mathematical formulas for TS and the VS calculation are shown below. Organic matter $(\mathrm{OM})$ is the percentage of VS/TS.

$$
\begin{aligned}
& \mathrm{TS}=\frac{\mathrm{A}-\mathrm{B}}{\mathrm{C}-\mathrm{B}} \\
& \mathrm{VS}=\frac{(\mathrm{B}+\mathrm{A})-(\mathrm{B}+\mathrm{D})}{(\mathrm{B}-\mathrm{A})}-\mathrm{B}
\end{aligned}
$$


A: weight of dried sample after $12 \mathrm{~h}$ at $105^{\circ} \mathrm{C}$, B: weight of container, C: weight of wet sample, D: weight of burnt sample after $3 \mathrm{~h}$ at $550^{\circ} \mathrm{C}$.

\section{pH measurement}

A mass of $10 \mathrm{~g}$ of digester slurry was added to a sample cup. The sample was mixed with water $(1: 1 \mathrm{v} / \mathrm{v})$. The slurry allowed setting, after vigorous stirring, for $1 \mathrm{~h}$ at room temperature. Then $\mathrm{pH}$ was measured by $\mathrm{pH}$ meter (Miller and Kissel 2010).

\section{Electric conductivity $(E C)$}

A weight of $5 \mathrm{~g}$ air dried sample was dissolved in $50 \mathrm{~mL}$ distilled water $(1: 10 \mathrm{w} / \mathrm{v})$ and shaken on an orbital shaker for $40 \mathrm{~min}$. Then supernatant was taken and EC of the supernatant was recorded using a pen type Total dissolved solids (TDS) meter (Peters et al. 2003). The results were expressed in $\mathrm{dSm}^{-1}$ according to Eq. 5 .

$$
\text { TDS in } \mathrm{mgL}^{-1}(\mathrm{ppm})=640 \times \mathrm{EC}\left(\mathrm{dSm}^{-1}\right)
$$

\section{Total organic carbon (TOC)}

Total organic carbon in the tested substrates was determined according to Page et al. (1982) by multiplying Organic matter percentage in 0.58 .

\section{Total Kjeldah nitrogen (TKN)}

For determination of organic and the inorganic forms of nitrogen, Total Kjeldahl Nitrogen (TKN) was analyzed by kjeldahl digestion method (APHA 1992). The substrate sample $(1 \mathrm{~g})$ was digested at $400^{\circ} \mathrm{C}$ for $60-90 \mathrm{~min}$. by adding $12 \mathrm{~mL}$ of concentrated sulphuric acid. For raising the boiling point, $3.5 \mathrm{~g}$ potassium sulfate $\left(\mathrm{K}_{2} \mathrm{SO}_{4}\right)$ was added. In addition to $0.4 \mathrm{~g}$ of copper sulfate $\left(\mathrm{CuSO}_{4}\right)$ was added as a catalyst. The tubes are left to cool off until the disappearance of white fumes. Subsequently, $50 \mathrm{ml}$ sodium hydroxide was automatically added to the sample for convert $\mathrm{NH}_{4}{ }^{+}$to $\mathrm{NH}_{3}$. The sample was distilled and condensed into $10 \mathrm{~mL}$ of boric acid solution, and the content was determined by acid-base titration. The titration endpoint was situated around $\mathrm{pH} 5.3$ with color change visualization from green to blue/purple and by addition of methyl red methylene blue indicator.

\section{Statistical analysis}

Results are presented as the mean \pm standard deviation (SD) from three replicates. The statistical analyses were carried out using SAS (v 6. 12). Data obtained were analyzed statistically to determine the degree of significance using one way analysis of variance (ANOVA) and $t$ test at probability level $\mathrm{p} \leq 0.05$.

\section{Results}

\section{Substrate characterization}

As shown in Additional file 1: Table S1, the park wastes (fresh and dry leaves) and cattle dung characterization revealed that the dried leaves had the highest TS content (84\%) and the highest value of $\mathrm{C} / \mathrm{N}$ (45.4). On the other hand, cattle dung had low TS content and $\mathrm{C} / \mathrm{N}$ ratio representing $17 \%$ and 13.6, respectively. Fresh leaves contained the 
highest VS and TOC representing $81.2 \%$ and $47.1 \%$, respectively. The highest percentage of TNK was recorded for cattle dung $(2.8 \%)$.

\section{Biogas and methane production}

The optimization conditions for biogas and methane production from the used substrate were investigated through two pretreatment processes including physical (milling) and chemical $\left(2.5 \% \mathrm{NaOH}\right.$ mixed with $2.5 \% \mathrm{NH}_{4} \mathrm{OH}$ for 15 days) followed by fungal treatment using Aspergillus terreus and Trichoderma viride for 7 days. Biogas production and process parameters were recorded during 70 days of retention time.

Biogas and $\mathrm{CH}_{4}$ yields of the pretreated and untreated substrate were measured. The daily and accumulative productions of biogas and $\mathrm{CH}_{4}$ obtained during 70 days of digestion from untreated and pretreated substrate were shown in Additional file 1: Table S2 and in Figs. 2 and 3. Daily biogas and $\mathrm{CH}_{4}$ production yields from the substrate were improved by the three pretreatment stages. The highest biogas and $\mathrm{CH}_{4}$ yield of 2.6 and $1.9 \mathrm{~L} / \mathrm{KgVS}$, respectively was obtained from pretreated substrate in the $28^{\text {th }}$ day compared to untreated substrate. On the other hand, the cumulative production of biogas for untreated substrate was $102.6 \mathrm{~L} / \mathrm{KgVS}$ which elevated to $125.9 \mathrm{~L} / \mathrm{KgVS}$ in case of pretreated substrate which showed $22.7 \%$ improvement compared to the biogas yield from untreated substrate. Cumulative $\mathrm{CH}_{4}$ production of pretreated and untreated substrate was 79.8 and $61.4 \mathrm{~L} /$ $\mathrm{KgVS}$, respectively with $30 \%$ improvement compared to the methane yield from untreated substrate. $\mathrm{CO}_{2}$ showed a reduction rate after pretreatment quantified by $11.9 \%$.

Statistical analysis of biogas, methane and $\mathrm{CO}_{2}$ production of untreated and pretreated substrate was shown in Additional file 1: Table S2. Substrate pretreatment had a significant improvement effect on the biogas and methane production after the 14th day; while being insignificant to that till the 56th day, and this showed the stability in the biogas and methane production through $\mathrm{AD}$ period. Beside, $\mathrm{CO}_{2}$ production showed significant decreasing values after 14th day and insignificant decrease from the 28th till 56th day.

\section{$\mathrm{pH}, \mathrm{EC}$ and $\mathrm{C} / \mathrm{N}$}

The results of $\mathrm{pH}, \mathrm{EC}$ and $\mathrm{C} / \mathrm{N}$ of the untreated and pretreated substrate are shown in Additional file 1: Table S3 and Fig. 4.

Insignificant decrease in $\mathrm{pH}$ values of untreated substrate till the 2nd week of $\mathrm{AD}$ followed by significant decreasing till the 8 th week. An increase in $\mathrm{pH}$ values was observed again at the beginning of the 8th week till the 10th week for both untreated and pretreated substrate. The changes in Electric conductivity (EC) of untreated substrate were observed (2.6-3.7 $\mathrm{dSm}^{-1}$ ) and showed directly proportional increasing along with the retention time. Moreover, EC values from the substrate were improved by its pretreatment (3.2-4.6 $\left.\mathrm{dSm}^{-1}\right)$. Statistical analysis showed significant changes in EC for both untreated and pretreated substrate. However, insignificant increase from the 56th day till the 70th day was recorded for the pretreated substrate. Additional file 1: Table S3 and Fig. 4, represented a significant change in $\mathrm{C} / \mathrm{N}$ ratio during $\mathrm{AD}$ process for 70 days. Pretreatment of the substrate improved $\mathrm{C} / \mathrm{N}$ in the first day to be 26.1 compared to untreated substrate (28.8), and decreased to be 12.3 at the end of $\mathrm{AD}$ time for pretreated substrate. In the same concern, a significant decreasing in $\mathrm{C} / \mathrm{N}$ for untreated substrate was observed through the period of retention time to be 18 at the end of AD time. 


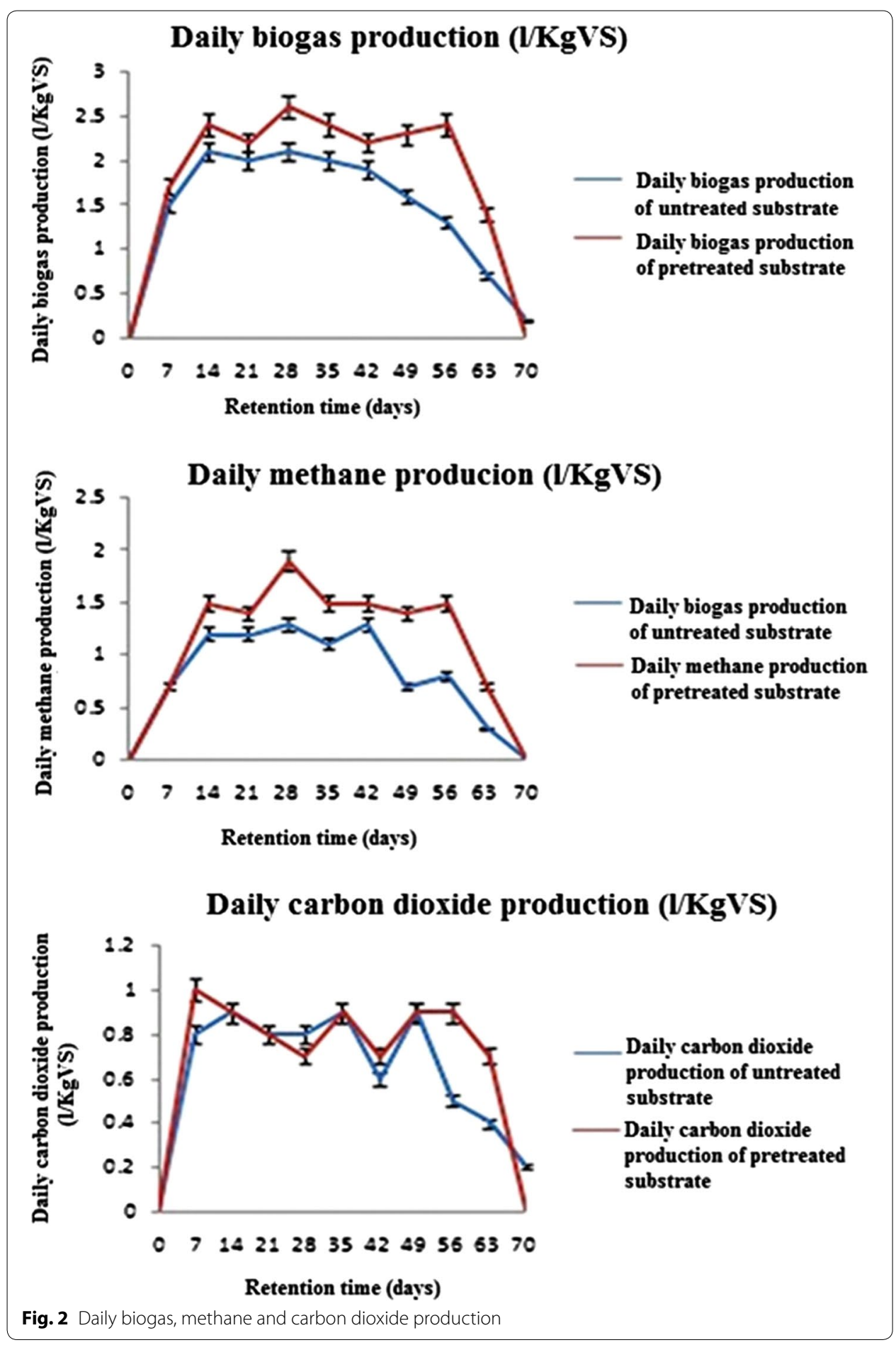

\section{Discussion}

Lignocelluloses are basically composed of carbohydrates (cellulose and hemicelluloses), lignin, and extraneous materials (Karimi et al. 2013). However, the compact crystalline structure where lignin physically protects the cellulose and hemicelluloses parts makes these materials more resistant to anaerobic digestion (Mosier et al. 2005). In the 


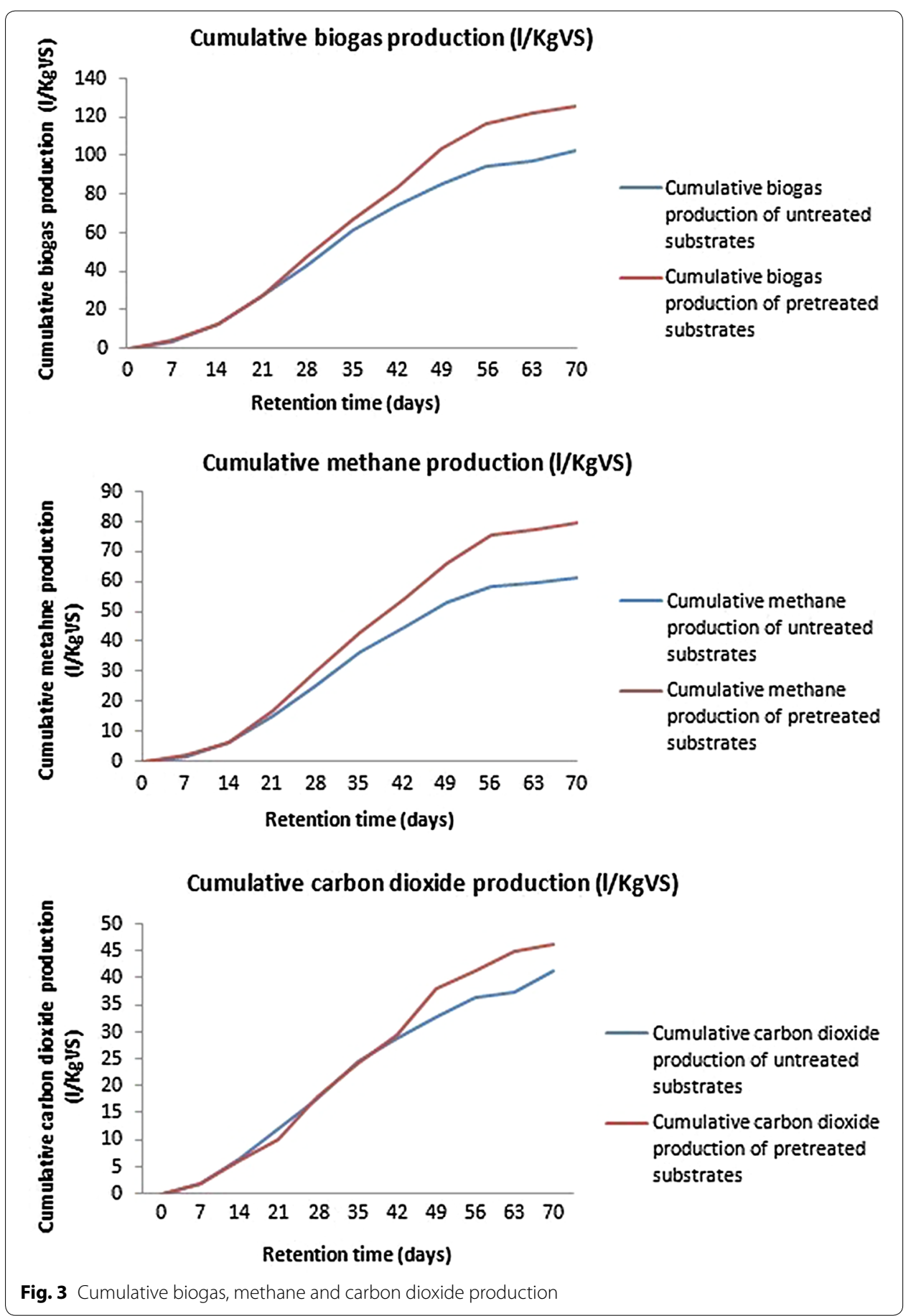

anaerobic digestion process, if a substrate is well enclosed in lignin structures, the type of disintegration of the substrate becomes important. The structure should be disrupted or defibrated rather than cut, because they are refractory to decomposition under anaerobic conditions (Pesta 2007). Without prior treatments, a slow hydrolysis might occur and biogas production could become low with a long retention time required to produce sufficient amount of biogas (Yu and Schanbacher 2010). In the present study, the used substrate was soaked in alkaline solution $\left(2.5 \% \mathrm{NaOH}\right.$ mixed with $\left.2.5 \% \mathrm{NH}_{4} \mathrm{OH}\right)$ 


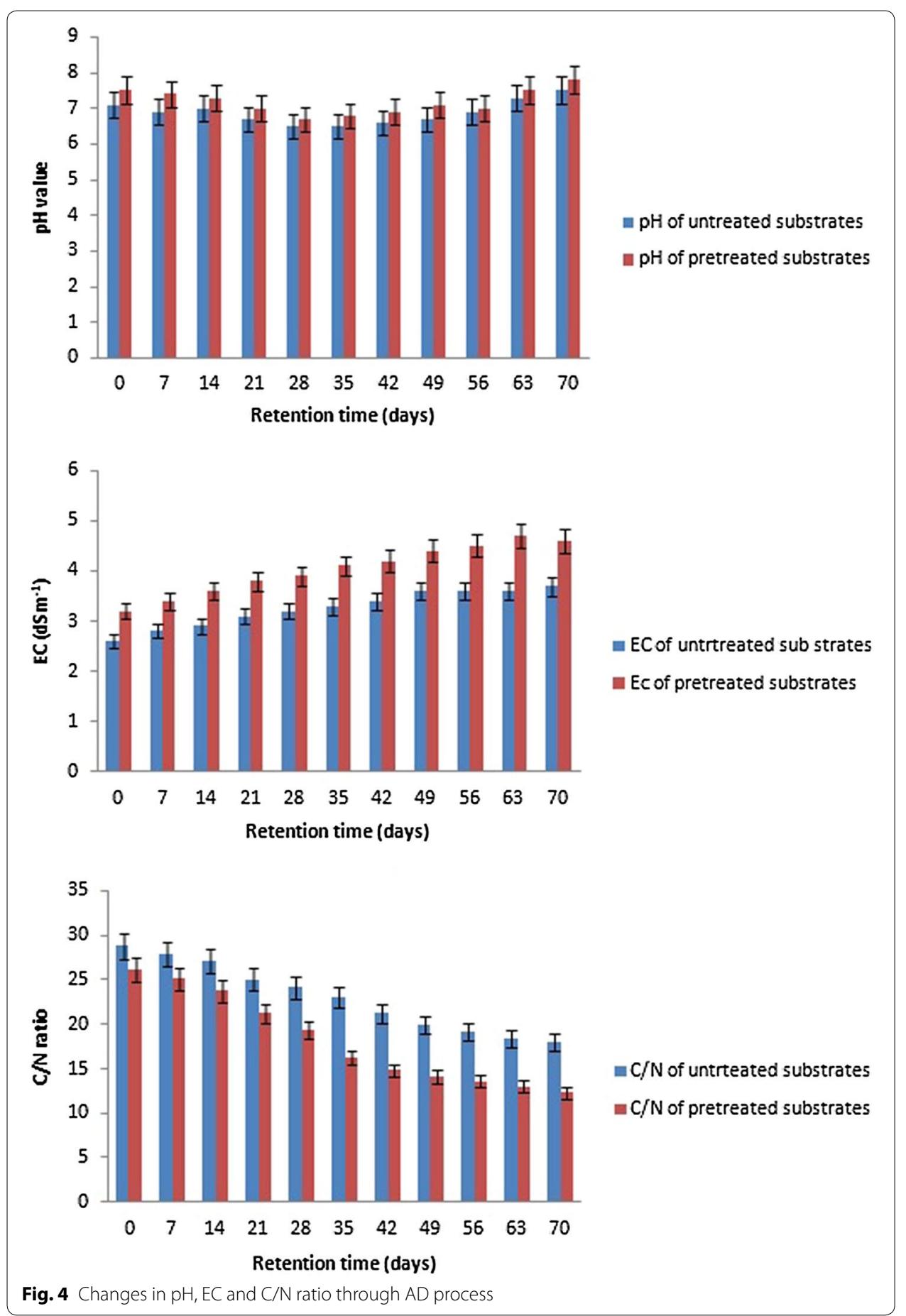

followed by fungal treatment for 7 days. Zuo et al. (2012) showed that a novel soaking pretreatment $(\mathrm{NaOH}$ and aqueous-ammonia) for corn stover was developed to remove lignin, swell the biomass, and improve enzymatic digestibility. Furthermore, alkalis help prevent decreases in $\mathrm{pH}$ during the acidogenesis process and increasing the efficiency of methanogenesis (Mao et al. 2015). Taherzadeh and Karimi (2008) showed that in 
alkaline pretreatment the biomass is soaked by alkaline solution at relatively low temperature for a certain amount of time. Zhang et al. (2011) compared the results of biogas production from corn straw which was subjected to $8 \% \mathrm{NaOH}, 5 \%$ ammonia and $4 \%$ urea pre-treatments at an ambient temperature for 20 days prior to anaerobic digestion. He et al. (2008) showed a significant increase in biogas yield in batch tests using rice straw pretreated with $6 \%$ solid $\mathrm{NaOH}$ for 3 weeks at ambient temperature. Ghosh and Bhattacharyya (1999) studied white-rot fungi and reported their ability on complete lignin degradation, and their application has been suggested for partial delignification to increase digestibility. In the same concern, Song et al. (2013) reported that the pretreatment with white-rot fungi can effectively remove lignin and decompose the biomass structure to enhance subsequent enzymatic hydrolysis. As well as, alkali pretreatment led to delignification of lignocellulosic fibers and the substrate became easier to be biodegraded. Sambusiti et al. (2012) reported that recombination of different pretreatment methods led to a solubilization of holocellulose and lignin. Ishola et al. (2014) indicated the ability of recombination between physical, chemical and biological pretreatments to degrade cellulosic biomass and increase its digestibility and its effect on biogas and methane production.

In the current study, the methane yield was enhanced by $30 \%$ after the use of fungal (A. terreus and T. viride) and alkaline pretreatment (2.5\% $\mathrm{NaOH}$ mixed with $2.5 \%$ $\left.\mathrm{NH}_{4} \mathrm{OH}\right)$. Thus, the pretreatment used in this work was effective compared to Liew et al. (2011) who showed that the methane yield increased by $20 \%$ using $3.5 \% \mathrm{NaOH}$ on fallen leaves. Zheng et al. (2009) and Yu et al. (2014) reported that the simultaneous alkaline treatment not only helped to improve the digestibility of park wastes but also increased the buffering capacity of the digester to maintain suitable $\mathrm{pH}$, thus leading to significant increase in biogas and methane yield compared with no or low alkaline loadings. The biological pretreatment has been extensively studied due to its several advantages, such as non-toxicity, environmental friendly, no chemical requirement, mild environmental conditions and low energy requirements. However, long pretreatment time is needed because the rate of the biological hydrolysis is usually very low, which is the main disadvantage of biological pretreatment methods (Taherzadeh and Karimi 2008). The obtained results revealed the improved biogas production (22.7 \%) by chemically and biologically substrate pretreatment $(125.9 \mathrm{~L} / \mathrm{KgVS})$ compared to untreated substrate (102.6 L/KgVS). In addition, $\mathrm{CH}_{4}$ production of pretreated substrate $(79.8 \mathrm{~L} / \mathrm{KgVS})$ was improved than untreated one $(61.4 \mathrm{~L} / \mathrm{KgVS})$ by $30 \%$. On the other hand, carbon dioxide production was reduced by $11.9 \%$ after pretreatment. The present study showed the changes in $\mathrm{pH}$ values of untreated substrate from 7.1 to 7.5 after 70 days, and from 7.5 to 7.8 for pretreated substrate. The $\mathrm{pH}$ value of the $\mathrm{AD}$ substratum influences the growth of methanogenic microorganisms and the dissociation of some compounds relevant for the $\mathrm{AD}$ process, i.e. ammonia, hydrogen sulphide and organic acids (Al Seadi et al. 2008). Methane formation takes place within a relatively narrow $\mathrm{pH}$ range, between 5.5 and $8.5 \mathrm{ca}$., with an optimal range of between 7.0 and 8.0 for most methanogens (Al Seadi et al. 2008). Ho et al. (2013) stated that the drop occurred in $\mathrm{pH}$ values was due to the formation of volatile fatty acids after anaerobic digestion process, which caused a drop in $\mathrm{pH}$ value to turn the conditions favourable to methanogenic bacteria which consumed acetic acid and raise $\mathrm{pH}$ value again. Moreover, EC values of untreated substrate varied 
from 2.6 to $3.7 \mathrm{dSm}^{-1}$. However, in pretreated substrate EC reached to $4.6 \mathrm{dSm}^{-1}$ by the end of anaerobic digestion. The gradual increase in EC values might be due to high concentration of nutrient ions released during the organic matter mineralization. Bakili et al. (2014) and Okoroigwe et al. (2014) reported that the $\mathrm{C} / \mathrm{N}$ ratio must range from 20 to 30 to make a nutritional balance for microorganisms inside the digester. The current results showed that the $\mathrm{C} / \mathrm{N}$ ratio changed from 28.8 (untreated substrate) to 26.1 after physical, chemical pretreatment in addition to fungal (A. terreus and $T$. viride) treatment, revealing the effect of these pretreatment steps in improvement of $\mathrm{C} / \mathrm{N}$ ratio. The $\mathrm{C} / \mathrm{N}$ ratio of untreated and pretreated substrate showed a gradual decrease $\mathrm{C} / \mathrm{N}$ values along with retention time due to bacterial activity that consumes total organic carbon as well as using a small amount of nitrogen (Tchobanoglous et al. 1993). The content of organic matter and organic carbon decreased because of the physico-chemical pretreatment and fungal activities which can degrade cellulose and lignin and hence increase biogas production. Weiland (2010) reported that a ratio of around 30 is favourable for microbial cell metabolism. But lower $\mathrm{C} / \mathrm{N}$ ratio than $10-15$ leads to ammonium releasing and inhibition of bacterial growth. This explains, in the present study, the decreasing of biogas production after lowering $\mathrm{C} / \mathrm{N}$ ratio through anaerobic digestion. This decreasing in $\mathrm{C} / \mathrm{N}$ ratio may affect methanogenic bacteria and thus decreasing in methane yield.

\section{Conclusion}

Physical (milling), chemical $(\mathrm{NaOH}$ and $\mathrm{NH} 4 \mathrm{OH})$ pretreatment in addition to fungal $(A$. terreus and $T$. viride) treatment for park wastes and cattle dung substrate prior to AD was an efficient process for improvement of biogas and methane production. Moreover, further work is needed to ensure that the recycling of treated and untreated lignocellulosic wastes results in the improvement of agriculture.

\section{Additional file}

Additional file 1. In the supplemental material section results from park wastes and cattle dung characterization as well as statistical analysis of biogas, methane and $\mathrm{CO}_{2}$ daily and cumulative production of untreated and pretreated substrate in addition to statistical analysis of $\mathrm{pH}, \mathrm{EC}$ and $\mathrm{C} / \mathrm{N}$ of the untreated and pretreated substrate are presented.

\section{Authors' contributions}

SSA have been involved in the design of the study, isolation and identification of fungi, experiment set up, collecting data, writing, drafting and revising the manuscript and JZS revised the manuscript critically for important intellectual content. Both authors read and approved the final manuscript.

Author details

${ }^{1}$ Botany Department, Faculty of Science, Tanta University, 31527 Tanta, Egypt. ${ }^{2}$ Biofuels Institute, Jiangsu University, Zhenjiang 212013, China.

\section{Acknowledgement}

The authors like to thank Dr. Abd El-Fatah Abomohra (Botany Department, Faculty of Science, Tanta University, Egypt) for helping with statistical analysis for the given data and to Mr. Tamer S. El-Samahy for his assistance in collection of the samples. This work was funded by Egyptian Ministry of Higher Education and Scientific Research (MHESR), Supporting of Excellence Students Projects (SESP).

\section{Competing interests}

The authors declare that they have no competing interests.

Received: 9 January 2015 Accepted: 22 October 2015

Published online: 20 November 2015 


\section{References}

Al Seadi T, Rutz D, Prassl H, Köttner M, Finsterwalder T, Volk S, Janssen R (2008) Biogas Handbook. University of Southern Denmark Esbjerg, Esbjerg, pp 9-10

Alvarez CES, Miranda JL, Castro MR, Verdín GP, Pérez MAR, Hernández IC (2013) Alkaline pretreatment of Mexican pine residues for bioethanol production. Afr J Biotechnol 12(31):4956-4965

APHA (1992) Standard methods for the examination of water and wastewater, 18th edn. American Public Health Association, Washington

APHA (1995) Standard methods for the examination of water and wastewater, 19th edn. American Public Health Association, Washington

Bakili S, Gessesse A, Mtei K, Njau K (2014) Anaerobic digestion of banana winery effluent for biogas production. Int J Environ Prot Polic 2(5):168-173

Bi Y, Gao C, Wang Y, Li B (2009) Estimation of straw resources in China. Trans Chin Soc Agric Eng 25:211-217

Blackwell M (2011) The Fungi: 1, 2, 3 ... 5.1 million species? Am J Bot 98(3):426-438

Bochmann G, Montgomery LFR (2013) Storage and pre-treatment of substrates for biogas production. In: Wellinger A, Murphy JD, Baxter D (eds) The biogas handbook: Science, production and applications. Woodhead Publishing Limited, Cambridge (ISBN 978085709498 8)

Booth C (1971) The genus Fusarium, 1st edn. Commonwealth Mycological Institute, Kew Surrey, p 237

Chen HH, Lee AHI (2014) Comprehensive overview of renewable energy develop-ment in Taiwan. Renew Sustain Energy Rev 37:215-228

Chen H, Liu L, Yang Z, Li Z (2005) New process of Maize stalk amination treatment by steam explosion. Biomass Bioenerg 28:411-417

Drosg B, Alsaedi T, Braun R, Bochmann G (2013) Analysis and characterisation of biogas feedstocks. In: Wellinger A, Murphy JD, Baxter D (eds) The biogas handbook: science, production and applications. Woodhead Publishing Limited, Cambridge, UK

Elumalai S, Roa-Espinosa A, Markley JL, Runge TM (2014) Combined sodium hydroxide and ammonium hydroxide pretreatment of post-biogas digestion dairy manure fiber for cost effective cellulosic bioethanol production. Sustain Chem Process 2:12. doi:10.1186/2043-7129-2-12

Ergüder TH, Güven E, Demirer GN (2000) Anaerobic treatment of olive mill wastes in batch reactors. Process Biochem 36:243-248

Ghosh A, Bhattacharyya BC (1999) Biomethanation of white rotted and brown rotted rice straw. Bioprocess Eng 20:297-302

Gilman J (1959) A manual of soil fungi. The lowa state University Press, Ames

He Y, Pang Y, Liu Y, Li X, Wang K (2008) Physicochemical characterization of rice straw pretreated with sodium hydroxide in the solid state for enhancing biogas production. Energ Fuel 22:2775-2781

Ho DP, Jensen PD, Batstone DJ (2013) Methanosarcinaceae and acetate oxidizing pathways dominate in high-rate thermophilic anaerobic digestion of waste activated sludge. Appl Environ Microbiol 79(20):6491-6500

Holm-Nielsen JB, Al Seadi T, Oleskowicz-Popiel P (2009) The future of anaerobic digestion and biogas utilization. Bioresour Technol 100:5478-5484

Ishola M, Isroi B, Taherzadeh M (2014) Effect of fungal and phoshoric acid pretreatment on ethanol production from oil palm empty fruit bunches. Bioresour Technol 165:9-12. doi:10.1016/j.biortech.2014.02.053

Jiang X, Sommer SG, Christensen KV (2011) A review of the biogas industry in China. Energy Polic 39:6073-6081

Karimi K, Shafiei M, Kumar R (2013) Progress in physical and chemical pretreatment of lignocellulosic biomass. In: Gupta VK, Tuohy MG (eds) Biofuel technologies. Springer, Berlin, pp 53-96

Kong F, Engler C, Soltes E (1992) Effects of cell-wall acetate, xylan backbone and lignin on enzymatic hydrolysis of aspen wood. Appl Biochem Biotechnol 34-35:23-35

Liew LN, Shi J, LiY (2011) Enhancing the solid-state anaerobic digestion of fallen leaves through simultaneous alkaline treatment. Bioresour Technol 102:8828-8834

Mackulak T, Prousek J, Švorc L, Drtil M (2012) Increase of biogas production from pretreated hay and leaves using woodrotting fungi. Chem Pap 66:649-653

Manilla PN, Ogali RE, Uzoukwu BA (2001) Undergraduate chemistry fundamental principles. Timi Hyacinth Enterprises, Lagos

Mao C, Feng Y, Wang X, Ren G (2015) Review on research achievements of biogas from anaerobic digestion. Renew Sustain Energy Rev 45:540-555

Maramba FD (1978) Biogas and waste recycling: the Philippine experience: Maya farms division. Liberty Flour Mills Inc, Philippines

Miller RO, Kissel DE (2010) Comparison of soil pH methods onsoils of North America. Soil Sci Soc Am J 74:310-316

Mosier N, Wyman C, Dale B, Elander R, Lee YY, Holtzapple M et al (2005) Features of promising technologies for pretreatment of lignocellulosic biomass. Bioresour Technol 96:673-686

Moubasher AH (1993) Soil fungi in Qatar and other Arab countries. The Scientific and Applied Research Center, University of Qatar, Doha, p 566

Munk B, Bauer C, Gronauer A, Lebuhn M (2010) Population dynamics of methano-gens during acidification of biogas fermenters fed with maize silage. Eng Life Sci 10:496-508

Muñoz C, Hidalgo C, Zapata M, Jeison D, Riquelme C, Rivas M (2014) Use of Cellulolytic Marine Bacteria for Enzymatic Pretreatment in Microalgal Biogas Production. Appl Environ Microbiol 80:4199-4206. doi:10.1128/AEM.00827-14

Okoroigwe EC, Ibeto CN, Ezema CG (2014) Experimental study of anaerobic digestion of dog waste. Sci Res Essays 9(6):121-127

Page AL, Miller RH, Keeney DR (1982) Methods of Soil Analysis, 2nd edn. Amercen Society of Agronomy, Madison

Pesta G (2007) Anaerobic digestion of organic residues and wastes. In: Oreopoulou V, Russ W (eds) Utilization of byproducts and treatment of waste in the food industry. Springer, New York, pp 53-72

Peters J, Combs SM, Hoskins B, Jarman J, Kovar JL, Watson ME, Wolf AM, Wolf N (2003) Recommended methods of manure analysis (A3769). University of Wisconsin Extension. http://www1.uwex.edu/ces/pubs 
Petrikkou E, Rodriguez-Tudela JL, Cuenca-Estrella M, Gomez A, Molleja A, Mellado E (2001) Inoculum standardization for antifungal susceptibility testing of filamentous fungi pathogenic for humans. J Clin Microbiol 39:1345-1347

Sambusiti C, Ficara E, canziani R (2012) Physical, chemical and biological pretreatments to enhance biogas production from lignocellulosic substrates. Ph D Thesis, DICA (Department of Civil and Environmental Engineering), politecnico di Milano University, Italy

Sari FP, Budiyono B (2014) Enhanced biogas production from rice straw with various pretreatment : a review. Waste technol 2(1):17-25

Schell D, Harwood C (1994) Milling of lignocellulosic biomass. Appl Biochem Biotechnol 45-46(1):159-168. doi:10.1007/ BF02941795

Song Z, Yang G, Han X, Feng Y, Ren G (2013) Optimization of the alkaline pretreatment of rice straw for enhanced methane yield. BioMed Research International, (Article ID 968692

Sun JZ, Ding SY, Peterson DJ (2014) Biological conversion of biomass for fuels and chemicals —explorations from natural biomass utilization systems. The RSC energy \& environment. Royal Society of Chemistry (RSC), London (ISBN: 978-1-84973-424-0)

Taherzadeh MJ, Karimi K (2008) Pretreatment of lignocellulosic wastes to improve ethanol and biogas production: a review. Int J Mol Sci 9(9):1621-1651

Tchobanoglous G, Theisen H, Vigil SA (1993) Integrated solid waste management: engineering principles and management issues, 2nd edn. McGraw-Hill International, New York, p 978 (ISBN-13: 9780070632370)

Tippayawong N, Thanompongchart $\mathrm{P}$ (2010) Biogas quality upgrade by simultaneous removal of $\mathrm{CO}_{2}$ and $\mathrm{H}_{2} \mathrm{~S}$ in a packed column reactor. Energy 35(12):4531-4535

Weiland P (2010) Biogas production: current state and perspectives. Appl Microbiol Biot 85(4):849-860

Williams AG, Withers S (2012) Sutherland AD: The potential of bacteria isolated from ruminal contents of seaweed-eating north ronaldsay sheep to hydrolyse seaweed components and produce methane by anaerobic digestion in vitro. Microbial Biotechnol 6(1):45-52

Wojciech MB (2012) Benefits of biogas upgrading to biomethane by high-pressure reactive solvent scrubbing. Biofpr 6:12-20

Wu B (2012) Integration of mixing, heat transfer, and biochemical reaction kinetics in anaerobic methane fermentation. Biotechnol Bioeng 109(11):2864-2874. doi:10.1002/bit.24551

Yu Z, Schanbacher F (2010) Production of methane biogas as fuel through anaerobic digestion. In: Singh OV, Harvey SP (eds) Sustainable biotechnology. Springer, Netherlands, pp 105-127

Yu L, Bule M, Ma J, Zhao Q, Frear C, Chen S (2014) Enhancing volatile fatty acid (VFA) and bio-methane production from lawn grass with pretreatment. Bioresource Technol 162:243-249

Zhang L, Lee Y-W, Jahng D (2011) Anaerobic co-digestion of food waste and piggery wastewater: focusing on the role of trace elements. Bioresour Technol 102:5048-5059

Zheng MX, Li XJ, Li LQ, Yang XJ, He YF (2009) Enhancing anaerobic biogasification of corn stover through wet state $\mathrm{NaOH}$ pretreatment. Bioresour Technol 100(21):5140-5145

Zheng Y, Zhao J, Xu F, Li Y (2014) Pretreatment of lignocellulosic biomass for enhanced biogas production. Prog Energy Combust Sci 42:35-53

Zuo Z, Tian S, Chen Z, Li J, Yang X (2012) Soaking pretreatment of corn stover for bioethanol production followed by anaerobic process. Appl Biochem Biotechno 167:2088-2102

\section{Submit your manuscript to a SpringerOpen ${ }^{\circ}$ journal and benefit from:}

- Convenient online submission

- Rigorous peer review

- Immediate publication on acceptance

- Open access: articles freely available online

- High visibility within the field

- Retaining the copyright to your article

Submit your next manuscript at $\mathbf{s p r i n g e r o p e n . c o m ~}$ 